\title{
G 301
}

\section{ヴェトナムの中小企業における労㗢安全衛生マネジメントシステム構築の支援}

\section{O川上 剛（ILOアジア太平洋総局）、小木和孝(労働科学研究所）}

【ねらい】ILO では 2001 年にILO 安全衛生マネジメントシステムガイドライン（ILO-OSH2001）を発 行しその普及を図っている。ILO-OSH2001 は中小企業においても実践的なツールとして活用されること を目ざしている。今回ヴェトナムの中小企業において ILO-OSH2001 活用のためのトレーニングを開催 した。特にワイズ方式参加型トレーニングとILO-OSH2001 の組み合わせによる相乗効果をねらった。

【方法】ヴェトナム南部カント省において中小企業 12 社を対象に ILO-OSH2001 を用いて労㗢安全衛生 マネジメントシステム構築支援トレーニングを実施した。各社ともILO ワイズ方式参加型改善トレーニ ングを通して安全保健改善の基本的な実践経験を有していた。トレーニングでは参加した各社労使代表 に ILO-OSH2001 の 5 つの要素（ポリシー、組織、計画、評価、システム改善）を解説し、その後グループ ワークを通して各社が実際にマネジメントシステムを作成した（図 1)。参加者の各要素についての理 解を容易にするために具体的な事例を示した。トレーニング 2 カ月後にフォローアップ訪問を実施した。

【結果と考察】演習を含む 2 日間のトレーニングとフォローアップを組み合わせることで、有効に OSHMS 構築導入が図れることが確かめられた。トレーニング後の質問紙調査から参加者はトレーニン グの内容をよく理解していた。上記の 5 要素について具体例を提示することが重要であった。フォロー アップ訪問から各社が安全保健ポリシーを定めてさまざまな安全保健改善活動を計画・実施しているこ とが確認できた（表 1 ）。労使の直接参加を促進するためにチェックリストによるリスクアセスメント の共同実施など具体的な労働者参加促進の努力が行われていた。一方、リスクアセスメントの進め方や OSHMS の評価および監査については現地専門家との共同作業による継続支援が重要であると考えられ た。また、自分たちの努力・達成に対する何らかの認証を求める必要性も指摘されていた。

【結論】ワイズ方式安全保健低コスト改善とILO-OSH2001 によるシステムアプローチの連携がヴェト ナムの中小企業における持続的安全保健改善活動を支援できることが確認できた。

（本研究はカント省労衝衛生・環境センターとの共同研究である）

図 1 ILO-OSH2001 トレーニングの進め方

第 1 日

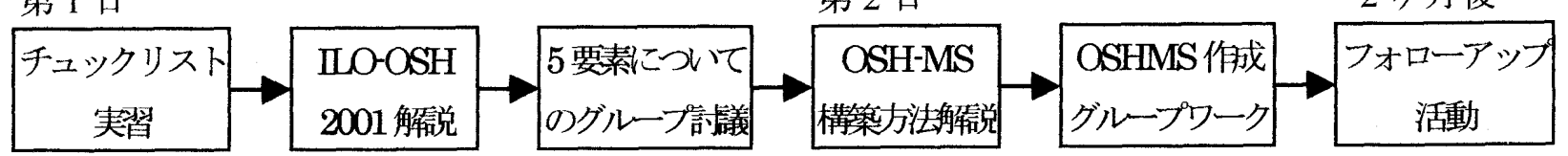

表 1 フォローアップ訪問で確かめられたトレーニング効果と支援ニーズ

\begin{tabular}{l|l}
\hline \multicolumn{1}{c|}{ 達成度の高かった項目 } & \multicolumn{1}{|c}{ 今後さらに支援が必要な項目 } \\
\hline 安全保健ポリシーの作成 & 効果的なリスクアセスメント手法 \\
年間活動計画の策定 & 中小企業向き改善事例提供 \\
低コスト改善の継続意思 & マネジメトシステム評価システム \\
労使の参加と役割分担の設定 & 各社の達成への認証システム \\
\hline
\end{tabular}

